\title{
THE ANALYSIS OF ENGLISH LOAN AND BORROWING WORDS USED BY INFORMATION AND TECHNOLOGY WRITERS IN THESIS ABSTRACTS
}

\author{
Luh Mas Ariyati
}

\begin{abstract}
.
An analysis on a field of linguistics that is English loan words can cause problems, such as problems of spelling and pronunciation, or even the change in meaning of the English borrowed words. This research is expected to give contribution to the society in general should be aware of the practical use of English loan words in Indonesian. In particular, the IT people can spell and write all the English borrowed words correctly in their writing in accordance with the rules of EYD, especially in formal writing. For EFL teachers and students, this study is aimed to explain practical inputs in teaching ESP writing, loan words, and the development of loan words in relation to linguistics, particularly loan words, such as definitions of loan words, patterns of borrowing and reasons for borrowing. Furthermore, the Indonesian lexicologist, can use the findings of the study to develop the glosarium into comprehensive IT dictionary deriving from English words including how to spell and pronounce them correctly.
\end{abstract}

Keywords: English Loan and Borrowing Words, Linguistics, The rules of EYD

It is a fact that English has influenced the way people communicate in Indonesian. As a foreign or second language for many people, English is foreseeable to replace the use of Indonesian in many instances. People, who can speak English, have the awareness of using English to communicate with English speaking people, to pursue better career, and to increase their income either in Indonesia or overseas. Consequently, a significant number of the middle as well as the upper class families send their children to school using English as medium of instruction. On the other hand, Bahasa Indonesia (Indonesian), one of the biggest stumbling blocks of English language teaching in Indonesia, poses a greater 'threat' to English as it is becoming more firmly established in all walks of life (Sadtono, 2004). Several state junior and high schools also set-up more than one bilingual class to pursue the same target.

This intense exposure of English both formal and informal has also forced people to explore this international language frequently. In addition, people with English educational background are presently not only able to read but also to write articles and books in English. English is a foreign language in Indonesia but the use of English is inevitable as people realize its importance. In Indonesia, the proportion 
of English teaching in formal education is predominant because this process allows the students to obtain the language optimally. At university level, students are given different approach in learning the language by reading a lot of English textbooks that are related to the students major. The objective of teaching is to introduce English for a specific purpose. Meanwhile, the other prominent area of English for the student is the use of information technology (IT) so that essential information of their study can be easily accessed by browsing the internet.

Referring to the above conditions, many people agree that there are two major concerns in the development of this emerging nation, namely English and IT. People, who master both subjects, will be able to compete in the global competition (Lee, 2008).

The IT itself is currently a very popular term in the globalization era. IT has become popular to broaden the term to explicitly include the field of electronic communication so that people tend to use the abbreviation ICT (Information and Communication of Technology). We can search the definition of this term from many resources such as business dictionary or through the internet, like the one in en.wikipedia.org/wiki/information_technology. IT as defined by the Information Technology Association of America (ITAA) is the study, design, development, implementation, support or management of computer based information systems, particularly software applications and computer hardware. IT deals with the use of electronic computers and computer software to convert, store, protect, process, transmit, and retrieve information, securely.

Today, the term IT has developed to encompass many aspects of computing and technology, and the term is more recognizable than ever before. The IT umbrella can be quite large, covering many fields. IT professionals perform a variety of duties that range from installing applications to designing complex computer networks and information databases. A few of the duties that IT professionals perform may include data management, networking, engineering computer hardware, database and software design, as well as the management and administration of the entire system. 
Since IT and the internet are used by people all over the world, the information is mainly written in English as an international language hence can be easily accessed and understood by them. Some of the information is written in other languages, e.g. Indonesian. The purpose of this is to help the Indonesian people to gain and understand the information more easily. However, several words cannot be expressed in Indonesian because those words are not Indonesian words. Even though there are substitute words in Indonesian, they are only used by certain communities such as Indonesian language experts. For example, many people are not familiar with the word (e.g. mangkus) hence they prefer to use and adopt the English word completely (e.g. effective) or try to 'fit' into Indonesian (e.g. efektif).

As indicated by its definition IT as a communication tool has given the students in Indonesia wider perspective in adopting resources from all over the world, especially information that is written in English. Unlike many other subjects in the university, Information Technology subject by far comparison in dealing with English term used by the technology as it needs to not only searching for information but also operating the system according to the rules that are commonly written in English.

Recognizing that the exposures of IT people to English are significantly high, there is possibility that Indonesian will use many English terms in communicating in IT community. The phenomenon of borrowing English seems to be inevitable nowadays as people have greater chance to contact and communicate with people worldwide (Hamid, 2006).

This study is intended to find out the percentage of the occurrence of each English IT loan word, describe the patterns of English loan words as used by IT people, the spelling of the borrowed words using EYD as reference, and lexicology approach of English loan words.

There are several out of many theories in bilingualism. Many people, no doubt, would think that a bilingual is a person who can speak and understand two languages, e.g. Indonesian and English or Indonesian and Mandarin. For most part, this understanding would be right. Weinreich (1968: 1) supported this and said that 
the practice of alternately using two languages will be called bilingualism and the person involved, called bilingual.

Furthermore, in his article 'the description of bilingualism', Mackey in Hoffman (1991) proposes a definition that incorporates Weinreich's alternate use of two languages and is preceded by Bloomfield's reservation with respect to the degree of proficiency, as quoted by Hoffman:

It seems obvious that if we are to study the phenomenon of bilingualism, we are forced to consider it is as something entirely relative. We must include over the use not only of two languages, but of any number of languages. We shall therefore consider bilingualism as the alternate use of two or more languages by the same individual (Hoffmann, 1991: 16).

Skutnabb-Kangas (1984: 90) states that a bilingual speaker is someone who is able to function in two (or more) languages, either in monolingual or bilingual communities, in accordance with socio-cultural demands made of individual's communicative and cognitive competence by these communities or by individual him/herself, at the same level as native speakers, and who is able positively to identify with both (or all) language groups (and cultures) or parts of them. Among several theories above, the last theory is very close to the current research within IT.

In the context of IT, bilingualism relates to the so-called jargon, which is known as terminology that relates to a specific activity, profession or group (en.wikipedia.org/wiki/jargon). Much like slang it develops as a kind of shorthand, to quickly express ideas that are frequently discussed between members of a group. In many cases a standard term may be given a more precise or specialized usage among practitioners of a field. In many cases this may cause a barrier to communication as many people may not understand.

More specifically, jargon is used in several fields, among which some are sports, religion, medicine, critical theory, politics and information technology (IT). In terms of IT and the internet, jargons are used by computer scientists, programmers, system architects, enthusiasts and hackers to communicate. The proper usage of these words is sometimes considered prerequisite for inclusion in these groups. 
Since the study is about borrowing words, it is appropriate to define what is actually meant by borrowed words. Longman Dictionary of Language defines borrowed word as a word or phrase which has been taken from one language and used in another language. For example, English has taken coup d'etat (the sudden seizure of government power) from French, al fresco (in the open air) from Italian, and moccasin (a type of shoe) from an American Indian language. When a borrowing is a single word, it is called a loan word.

Sometimes, speakers try to pronounce borrowed words as they are pronounced in the original language. However, if a borrowed word or phrase is widely used, most speakers will pronounce it according to the sound system of their language. For instance, French/garaz/ garage has become in British English/ gaerd:z/:/gaeridz/, though American English keeps something like the French pronunciation.

Linguists such as Fromkin and Rodman (1984: 309) define loan words as a process by which one language or dialect takes and incorporates some linguistic elements from another. Similarly, Gal (1979: 79) identifies loan words or borrowings as consisting of the introduction of single words or short idiomatic phrases from one language into the other.

Meanwhile, Robin (1964: 313) explains that loan words must be considered as those words, which are not in the vocabulary at one period and are in at subsequent one, without having been made of from the lexical stock of language or invented as entirely new creation as for example, certain name of products. Loan words, are in fact, entering language at all time, but both their frequency and source are temporarily by political or other factors leading to close cultural contacts of one sort or another.

Furthermore, some other linguists have different definitions about loan or borrowed words. For example, Hudson (1994: 18) says that borrowed word is a general and traditional word used to describe the adoption into a language of a linguistic feature previously used in another. Haugen (1950: 210) states that borrowing is the adoption of a linguistic expression from one language into another language when no term exists for the new object and concept. Grosjean (1982) uses 
the term 'language borrowing' to refer to terms that have passed from one language to another and have come to be used even by monolingual, and he distinguishes them from instances where the bilingual borrows items spontaneously and adapts their morphology, which he calls 'speech borrowing'.

It is obvious from the above statement that loan words or borrowings are not words which formally exist in one language and are not newly created. The loan words are new words which are adopted from another language through various factors such as politics and close cultural contacts.

In relation to borrowing, some of the main reasons for borrowing English words are as follows (Sadtono, 2004):

1. The pressure of modernization and globalization.

2. English is richer than Indonesian in vocabulary, ideas, concepts and words for tangible things.

3. Advance in science and technology producing new things, is communicated by means of English.

4. Impatient with translation.

5. Some English words are simply non-existent in Indonesian lexicon, and sometimes the idea itself is non-existent either.

6. Some English words may even become more popular than existing Indonesian equivalents.

7. English loan words are easier to remember when they are Indonesianized, particularly for those who know English.

8. The application of the principle of economy ('economization').

9. It is human nature, we need change and variety.

10. On the tip of the tongue.

11. Show-off.

According to Sadtono (2004), there are six patterns of borrowing, namely:

1. Total borrowing: the English words borrowed are transferred into Indonesian completely. There are two groups of words that can be categorized into total borrowing. First, they are simply spelled and pronounced as the original and 
for example, the word 'online'. Second, there are no changes in terms of spelling, pronunciation and meaning and for example, the word 'data'.

2. Partial borrowing: the English words borrowed are modified or adopted in terms of spelling and pronunciation. For example, the word 'modulation' becomes 'modulasi'.

3. Total modification of loan words: the English words borrowed are totally changed so that they bear no resemblance to the original. For example, the word 'case' becomes 'kasus'.

4. Borrowing with modified meaning: the English words are maintained fully or partially intact, but the meaning is slightly or totally changed. For example, the word 'manipulation' which has positive meaning becomes 'manipulasi' but then shows negative meaning.

5. Newly created words based on loan words: English loan-words ending in 'city' are usually transformed into '-sitas' in Indonesian. For example, the word 'university' becomes 'universitas'.

6. Partial phrase borrowing: the English phrase is partially borrowed, usually only the first words. For example, the word 'demonstration' becomes simply 'demo'.

According to EYD (2001), if appropriate terms are not available in Indonesian, foreign languages can be used. The new terms can be formed through translation, absorption and mix of absorption and translation. The list of IT loan words that was used in this study has been obtained from 20 abstracs of SNATI Seminar. The following stages were carried out to get the intended data for the study. Initially, any foreign words and its adoption into Indonesian were selected. It was then compared with "Kamus Ilmiah Serapan" by Kamarulzaman and Al Barrry (2005) to ensure that the words on the list were adopted from English and not from other foreign languages. There are two words were ommited from the list as it was adopted from Dutch. The last stage was to sort the words out using the IT Glossary produced by the Centre of Language of the Ministry of National Education to confirm that those words are classified into IT words. The IT Glosarry can be accessed in pusatbahasa.diknas.go.id/glosarium/index.php. The website feature can 
be seen in Appendix 3. There are three categories in the IT glossary known as precisely (the English word has the exact corresponding word), start with (the IT words or phrase is started with the selected loan word) and contain (the IT loan word exists in the phrase but not at the beginning) the English words. However, only precise words were taken and analyse further.

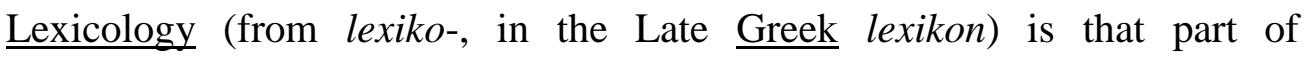
linguistics, which studies words, their nature and meaning, words' elements, relations between words (semantical relations), words groups and the whole lexicon (en.wikipedia.org/wiki/lexicology).

The term first appeared in the $\underline{1820 \mathrm{~s}}$, though there were lexicologists in the straight meaning even before that. Computational lexicology as a related field (in the same way that computational linguistics is related to linguistics) deals with the computational study of dictionaries and their contents. An allied science to lexicology is lexicography, which also studies words in relation with dictionaries - it is actually concerned with the inclusion of words in dictionaries and from that perspective with the whole lexicon. Therefore lexicography is the theory and practice of composing dictionaries. Sometimes lexicography is considered to be a part or a branch of lexicology, but the two disciplines should not be mistaken: lexicographers are the people who write dictionaries, they are at the same time $\underline{\text { lexicologists }}$ too, but not all lexicologists are lexicographers. It is said that lexicography is the practical lexicology; it is practically oriented though it has its own theory, while the pure lexicology is mainly theoretical.

\section{Methodology:}

\section{Research Design}

In line with the nature of the study, this research can be regarded as lexical analysis as a part of content analysis. Source of data was written texts where classes of data were collected and studied to discern patterns and formulate principles that might guide future action. This is also completed with survey questionnaire given to several IT students where behaviors, beliefs and observations of the specific group are identified, reported and interpreted (www.languages.ait.ac.th). 
Furthermore, according to Hostli in Susanto (2003: 64) content analysis can be employed (1) to describe the characteristics of the content, (2) to make inferences about the causes of the content, and (3) to make inferences about the effect of the content. In this study, this research technique was applied primarily to analyze the English loan-words as the manifest content of communication being described since they are used by IT students in writing their thesis abstracts. Furthermore, it was used to make inferences about the percentage of occurrences of the loan-words and the spelling of the loan-words based on EYD rules, where the rules of EYD issued by the Ministry of National Education of the Republic of Indonesia was the basic tool to evaluate the current work.

The research is also an etymology study since it concerns the origins of the words, English loan words used by IT people in writing thesis abstracts, and changing of the word including changing of meaning, pronunciation, spelling or part of speech of the words. In addition, the study also attempted to analyze the pattern of the borrowed words.

\section{The Research Instruments}

The study has characteristics attempted to understand not one but multiple realities in explaining English loan words used by IT people in written communication such as seminar abstract.

Knowing the focus of this study, the writer herself was the instrument of this research. Enhanced with theories in lexicology, such as loan words, pattern of borrowing, EYD rules, lexicology and content analysis, she was actively involved in observing, classifying and processing the data. Based on Robson (1995:15), the research observer takes the investigation on a role than that of a passive observer. The observer in this study is the research instrument who is actively collecting data and processing them.

Questionnaire was also designed and distributed as the second research instrument to corroborate the result of data analysis. Before arriving at the final questionnaire, a pilot survey was carried out in order to find out whether the questions brought out the expected answers. The list of IT words was taken from 
common Indonesian IT terms. It was then followed with further survey with 27 respondents with the same form and list of words. Finally, the researcher conducted a survey with the same form of question but the list of loan words was extracted from the comparison and analysis of IT Glossary to give a better result.

\section{The Procedure of Data Analysis}

There are four main procedures (and completed by a conclusion) employed in the current research in order to analyze the data that are in accordance with the nature of the study. They were as follows:

1. All assumed English words and loan words were selected from the 20 chosen SNATI abstracts.

2. As mentioned by Hoffman (1991) about his bilingualism theory, we must include over the use not only of two languages, but of any number of languages. Due to the fact that the study was about English loan words, 'kamus kata serapan' first edition 2001 is used in the study in order to ensure that the loan words are really from English words.

3. The loan words adopted in those abstracts were then compared with the Indonesian IT Glossary classification from the website of the Ministry of National Education which has three types of words namely precise (persis), started with (dimulai dengan) and contain (memuat). Further analysis is focused on the precise types.

4. A theory of six patterns of borrowing proposed by Sadtono (2004: 4) were employed, namely: the total borrowing, partial borrowing, total modification of loan words, borrowing with modified meanings, newly created words based on loan words, and partial phrase borrowing to identify the pattern of the precise IT words

5. The study is also aimed at finding out the percentage of each pattern of the borrowed words and the following statistical formulae to quantify the percentage of each pattern of the borrowing.

$P_{1}=\frac{\Sigma P_{1}}{\Sigma P_{1}+\Sigma P_{2}+\Sigma P_{3}+\Sigma P_{4}+\Sigma P_{5}+\Sigma P_{6}} x 100 \%=\ldots \ldots \%$ 


$$
\begin{gathered}
P_{2}=\frac{\Sigma P_{2}}{\Sigma P_{1}+\Sigma P_{2}+\Sigma P_{3}+\Sigma P_{4}+\Sigma P_{5}+\Sigma P_{6}} x 100 \%=\ldots \ldots \% \\
P_{3}=\frac{\Sigma P_{3}}{\Sigma P_{1}+\Sigma P_{2}+\Sigma P_{3}+\Sigma P_{4}+\Sigma P_{5}+\Sigma P_{6}} x 100 \%=\ldots \ldots \% \\
P_{4}=\frac{\Sigma P_{4}}{\Sigma P_{1}+\Sigma P_{2}+\Sigma P_{3}+\Sigma P_{4}+\Sigma P_{5}+\Sigma P_{6}} x 100 \%=\ldots \ldots \% \\
P_{5}=\frac{\Sigma P_{5}}{\Sigma P_{1}+\Sigma P_{2}+\Sigma P_{3}+\Sigma P_{4}+\Sigma P_{5}+\Sigma P_{6}} x 100 \%=\ldots \ldots \% \\
P_{6}=\frac{\Sigma P_{3}}{\Sigma P_{1}+\Sigma P_{2}+\Sigma P_{3}+\Sigma P_{4}+\Sigma P_{5}+\Sigma P_{6}} x 100 \%=\ldots \ldots \%
\end{gathered}
$$

Where,

$\mathrm{P} 1=$ total borrowing

$\mathrm{P} 2=$ partial borrowing

P3 = total modification of loan words

P4 = borrowing with modified meaning

P5 = newly created words based on loan words

P6 = partial phase borrowing

$\square \mathrm{P} 1 \quad=$ a number of total borrowing

$\square \mathrm{P} 2 \quad=$ a number of partial borrowing

$\square \mathrm{P} 3 \quad=$ a number of total modification of loan words

$\square \mathrm{P} 4 \quad=$ a number of borrowing with modified meaning

$\square \mathrm{P} 5 \quad=$ a number of newly created words based on loan words

$\square$ P6 = a number of partial phrase borrowing

6. Then, the researcher applied the rules of EYD to describe whether the spellings of the borrowed words applied by the writer in the abstracts are in accordance with EYD rules or not.

7. Finally, the researcher recorded the data in the form of words rather than sentences. Through this procedure, it can be seen if the loan words underwent changes in parts of speech or not.

\section{Results:}

\section{The Percentage of the Occurrences}


In order to calculate the percentage of the occurrence of the English loan words used in a text, 20 seminar abstracts from a conference called SNATI were selected. The results varied between $18 \%$ and $48 \%$. The average was approximately $30 \%$ indicated that one-third of the abstract are dominated by English words. The purpose of the study is to provide a description of English loan words employed by the writers of IT when they wrote their thesis abstracts. The titles of the abstract are as follows:

1. Pengelolaan proyek pengembangan perangkat lunak dengan Al-fresco.

2. Pelajaran dari implementasi e-government di Sragen.

3. Pemanfaatan GIS untuk e-agriculture dalam rangka mengatur keseimbangan produksi tanaman holtikultura

4. Pemanfaatan online geographic information pada system mobile resto reservation berbasis GPRS dan $3 \mathrm{G}$.

5. Pembuatan aplikasi pengolah kata sederhana.

6. Pemodelan proses bisnis B2B dengan BPMN (studi kasus pengadaan barang pada divisi logistik).

7. Pengaruh faktor pemicu terhadap tingkat partisipasi diskusi dalam student centered e-learning environment.

8. Pengembangan aplikasi sistem pakar pendiagnosis gangguan pendengaran dan kelainan telinga.

9. Pengembangan perangkat lunak sistem kendali dan pengawasan menggunakan relay on off berbasis SMS dan database untuk data histories.

10. Pengembangan perangkat keras pengiriman data GPS berbasis mikrokontroler untuk mendukung sistem informasi pelacakan kereta api.

11. Peningkatan efektivitas akses internet dengan menggunakan fasilitas internet protocol virtual private network (IP VPN) dan manajemen bandwidth dengan router mikrotik (studi kasus jaringan komputer untuk sekolah pada Kabupaten Magelang)

12. Penyimpangan data RDF dengan menggunakan database relasional.

13. Perancangan algoritma genetika untuk menentukan jalur terpendek. 
14. Perancangan aplikasi SMS reminder guna membantu mempercepat penyelesaian waktu studi mahasiswa di Jurusan Informatika, FTI - UII.

15. Perancangan host-based intrusion detection system berbasis artificial neural network.

16. Perancangan roket terkendali penembak pesawat dilengkapi chip yang terintegrasi algoritma cerdas.

17. Perbaikan algoritma penggalian frequent closed itemset charm

18. Performansi neuro fuzzy untuk peramalan data time series.

19. Prediksi penjualan dengan neuro fuzzy.

20. Prototipe sistem entri nilai akademik berbasis disconnected application dengan XML web service.

Table 1 showed the frequency and percentage of occurrences after satisfying the criteria of IT loan words provided by IT Glossary.

Table 1. The frequency and percentage of the borrowed words

\begin{tabular}{|l|l|c|c|c|}
\hline $\begin{array}{c}\text { Patterns of } \\
\text { Borrowing }\end{array}$ & Words & $\begin{array}{c}\text { Number of } \\
\text { Appearance }\end{array}$ & $\begin{array}{c}\text { Percentage } \\
\text { c.f. total } \\
\text { words } \\
(\%)\end{array}$ & $\begin{array}{c}\text { Percentage } \\
\text { c.f. total IT } \\
\text { words } \\
(\%)\end{array}$ \\
\hline 1.Total borrowing & Data & 24 & 0.73 & 16.55 \\
& Internet & 13 & 0.40 & 8.97 \\
& Network & 8 & 0.24 & 5.52 \\
& Database & 6 & 0.18 & 4.14 \\
& Intranet & 5 & 0.15 & 3.45 \\
& Online & 5 & 0.15 & 3.45 \\
& Gateway & 2 & 0.06 & 1.38 \\
& Basic & 2 & 0.06 & 1.38 \\
& Protocol & 4 & 0.12 & 2.76 \\
& Open & 1 & 0.03 & 0.69 \\
& Device & 2 & 0.06 & 1.38 \\
& Server & 4 & 0.12 & 2.76 \\
& Menu & 1 & 0.03 & 0.69 \\
& Word & 1 & 0.03 & 0.69 \\
& Freeware & 1 & 0.03 & 0.69 \\
& Application & 1 & 0.03 & 0.69 \\
& Multimedia & 1 & 0.03 & 0.69 \\
& Port & 1 & 0.03 & 0.69 \\
& On & 1 & 0.03 & 0.69 \\
& Off & 1 & 0.03 & 0.69 \\
& Relay & 1 & 0.03 & 0.69 \\
& Monitor & 1 & 0.03 & 0.69 \\
\hline
\end{tabular}




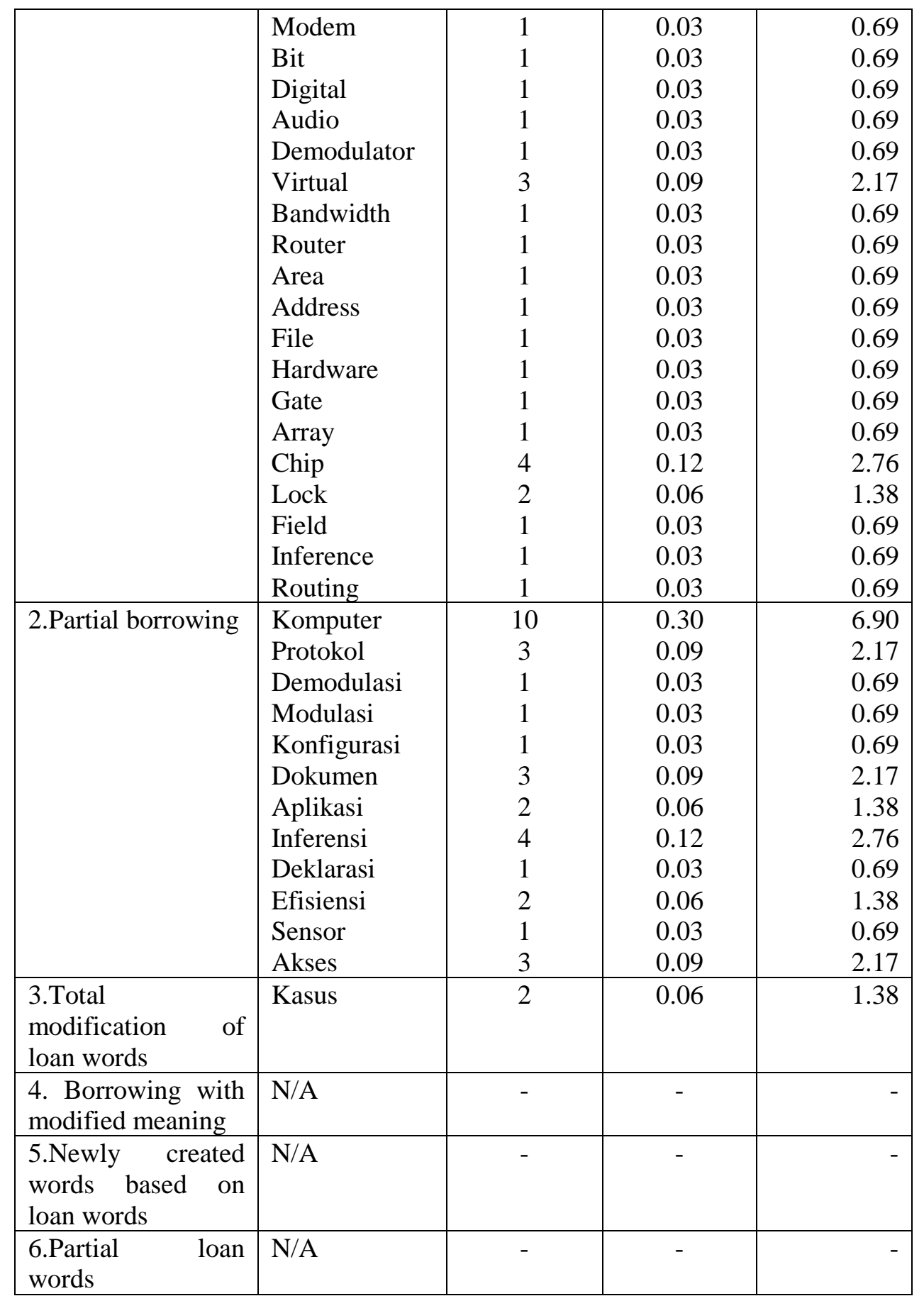

\section{Patterns of English Loan Words}

Theoretically, there are six patterns of English loan words, i.e. (1) total borrowing, (2) partial borrowing, (3) total modification, (4) borrowing with modified meaning, (5) partial phrase borrowing, and (6) newly created words based on loan words (Sadtono, 2004). However, only three patterns of those kinds of the borrowing were found in the study, i.e. total borrowing, partial borrowing, and total modification of loan words. 


\section{Total Borrowing}

The study discovered that there are two groups of words that can be categorized into total borrowing. Firstly, total borrowing means that the English loan words are transferred into Indonesian completely (Sadtono, 2004: 3). This means that when English words are adopted into Indonesian, they are simply spelled and pronounced as the original; there are no changes in terms of spelling, pronunciation and meaning. For example, the word 'online' which appear in abstracts 4 and 7; the word 'internet' appears in abstracts 7, 9, 11, 12 and 20. Those borrowed words are spelled as in the original form. In addition, there is no change in terms of meaning of those borrowed words.

Secondly, other words which are considered as total borrowing are those spelled as the original but pronounced differently. For examples, the word 'data' in abstracts 3, 9, 10, $12,13,16,17$ and 18, and the word 'menu' in abstract 4 . The borrowed words, 'data' and 'menu' are still spelled the same as the source words. The word 'data' is pronounced [deItə] in English, but it is pronounced $[\mathrm{d} \Lambda \mathrm{t} \Lambda]$ in Indonesian. Meanwhile, the word 'menu' is pronounced [menju:] in English, but it is pronounced [menu] in Indonesian. Despite those words pronounced differently from the original, they are still spelled the same as the source words. Those words still do not undergo change in the meaning and consequently those words are still categorized as total borrowing.

\section{Partial Borrowing}

Indonesian writers and IT people, in general, do not only borrow the English words in the form of total borrowing but also they adopt those in the form of partial borrowing. The people intend to modify and adapt the spelling and pronunciation of the English words into Indonesian. Sadtono (2004: 4) stated that partial borrowing is the English borrowed words which are modified and adapted in terms of spelling and pronunciation. The writer of this study discovered that IT people applied plenty of partial borrowing, a few of which are 'modulasi' (abstract 10), 'konfigurasi' (abstract 9), and 'protokol' (abstract 10).

The word 'modulasi' ending in '-si' actually comes from an English word 'modulation' ending in '-tion'. Due to the fact that the suffix 'ion' changes into 'si' the word 'modulation' which is pronounced ['modju:læen] changes its spelling into 'modulasi' and it is pronounced [modulasi]. Therefore, the borrowed word 'modulasi' is considered as partial borrowing because the borrowed word is modified and adapted in terms of spelling and pronunciation. 
The next is the word 'konfigurasi' beginning with a consonant ' $\mathrm{k}$ ' derived from an English word 'configuration' starting with a consonant 'c'. Inasmuch as English words beginning with a consonant ' $c$ ' changes into ' $\mathrm{k}$ ' in Indonesian. The word 'configuration' which is pronounced [kən,fIgə'reI $[\mathrm{n}$ ] changes its spelling into konfigurasi [konfigurasi]. As can be seen, the borrowed word undergoes change in spelling and pronunciation. Therefore, the word belongs to partial borrowing.

The same as above is the word 'protocol' which is pronounced [proutəkol] in English and changed into Indonesian as 'protokol' and pronounced [protokol]. Since the English word borrowed is modified and adapted in terms of spelling and pronunciation, the borrowed word is considered as partial borrowing.

\section{Total Modification of Loan Words}

Besides adopting English words totally or partially, the researcher also found the changing of the spelling and pronunciation of the borrowed words so that they are different from the original. Therefore, it is difficult for us to recognize the original form of the borrowed words. This is in line with Sadtono (2004: 4), who stated that the total modification of loan words occur when the English borrowed words are totally changed so that they bear no resemblance to the original such as 'kasus' which came from an English word 'case'. If we search the borrowed word, it does not resemble the original, since the English word 'case' [keIs] was totally changed in its spelling and pronunciation into 'kasus' [kasus] in Indonesian. Due to the change in the spelling and pronunciation of the borrowed words making it dissimilar to the donor word, the borrowed word then is categorized as total modification of loan words.

\section{Borrowing with Modified Meaning}

When a certain language adopts words from another language, such as Indonesian adopting words from English, there will be many kinds of changes in the borrowed words, one of which is an obvious kind of change in meaning. This is true since it is supported by Wardhaugh (1977: 210) asserting that once a word comes into a certain language, no matter what their origin is, it is subject not only to the rule of pronunciation but also semantic change, that is change in meaning. In line with this, Hoffman (1991: 101) states that there is often some changes in the meaning of the borrowed word although it is only in the context in which it is used. In addition, according to Sadtono (2004: 4), in borrowing with modified 
meaning, the English words are kept fully or partially intact but the meaning is slightly or totally changed. However, none of the current IT words satisfy this category.

\section{Newly Created words Based on Loan Words}

There are no precise IT words of this type. Even though at the first stage of the research we found several English loan words with this criteria in the abstracts, such as the words 'universitas' and 'fakultas' in abstract 7. Newly created words based on loan words: English loan words ending in '-sity' or 'ty' are usually transformed into '-sitas' or 'tas' in Indonesian (Sadtono, 2004: 4). As we know that those words are derived from English words 'university' and 'faculty'. Because of English loan words ending in 'sity' or 'ty' are transformed into 'sitas' and 'tas', university becomes universitas and faculty becomes fakultas.

\section{Partial Phrase Borrowing}

The last pattern of borrowing is called partial phrase borrowing where English words are borrowed partially. For instance, the word 'minimum' is written as 'minim' and 'demonstration' as 'demo'. However, there is no example of this type in the current research.

\section{Comparison to EYD Rules}

According to EYD Rules, there are seven spelling terminologies in relation to the absorption of foreign terms, i.e. (1) phonemic spelling, (2) etymology spelling, (3) transliteration, (4) identity spelling, (5) spelling fit, (6) adoption of foreign consonant words, and (7) adjustment of foreign affixes. The last term is further divided into two, namely (1) adjustment of suffixes and (2) adjustment of prefixes. However, only the application of rules (1), (2), (5), (6) and (7) can be found in the current research.

Some words satisfy rules (1). For instance, the word 'dokumen' and 'akses' which are not written 'document' and 'access' as in the original form. Whereas, there is at least one word fulfilling rules (2) where in this case the forms are different although the pronunciation might be the same. For example, the word 'censor' with 'sensor'.

The remaining words satisfy spelling fit (rules 5), adjustment of foreign affixes (rules 7) or combination of both rules. Some of the examples are described as follows. The word 'access' becomes 'akses' follows the rule known as spelling fit 9 (where $c c$ in front of $e$ and $i$ becomes $k s$ ) and twin consonant rule (where ss becomes s). The word 'application' 
becomes 'aplikasi' follows twin consonant rule (where pp becomes p), spelling fit 6 (where $c$ in front of $a, o, u$ and consonant becomes $k$ ) and adjustment suffixes 18 (where -(a)tion become -(a)si). The word 'censor' becomes 'sensor' follows spelling fit 7 (where $\mathrm{c}$ in front of e, i, oe, and y becomes s).

Furthermore, the word 'computer' becomes 'komputer' follows spelling fit 6 rule (where $c$ in front of $a, o, u$ and consonant becomes $k$ ). The word 'configuration' becomes 'konfigurasi' following spelling fit 6 (where $c$ in front of $a, o, u$ and consonant becomes $k$ ) and adjustment suffixes 18 (where -(a)tion become -(a)si). The word 'declaration' becomes 'deklarasi' following spelling fit 6 (where $c$ in front of $a, o, u$ and consonant becomes $k$ ) and adjustment suffixes 18 (where -(a)tion becomes -(a)si). The word 'demodulation' becomes 'demodulasi' follows adjustment suffixes 18 (where -(a)tion become -(a)si). The word 'document' becomes 'dokumen' follows spelling fit 6 (where $c$ in front of $a, o, u$ and consonant becomes $k$ ) and consonant words at the end (rules 6) (where $-n t$ becomes $-n$ ).

In addition, the word 'efficiency' becomes' efisiensi' following twin consonant (spelling fit, rules 5) (where $f f$ becomes $f$ ) and adjustment suffixes 4 (where $-c y$ becomes si). The word 'inference' becomes 'inferensi' following adjustment suffixes 9 (where -ence becomes -ensi). The word 'protocol' becomes 'protokol' following spelling fit 6 (where $c$ in front of $a, o, u$ and consonant becomes $k$ ). The word 'relay becomes 'relai' following adjustment 53 (where $-y$ becomes $-i$ ).

However, the word 'case' becomes 'kasus' shows a peculiarity. The change of 'c' into ' $\mathrm{k}$ ' fulfill spelling fit $\mathrm{y}$, meanwhile the change of 'se' becomes 'sus' does not follow any types of the available rules. Therefore, the adoption of word 'case' into 'kasus' is said to violate the rules of EYD.

\section{Results of the Survey Questionnaire}

Explaining the result of data anaysis is not enough to answer the correlation between the data from the abstract and the influence to the development of lexicography, so that we need to obtain the supporting reason from the IT people through the Questionnaire which has been done 3 times, i.e. (1) pilot / try-out, (2) early survey, and (3) final survey.

\section{Pilot / Try-Out Survey on 20 Respondents}

A pilot is made out in order to find out the validity of the study. The purpose of the pilot is to test the question in the questionnaire, so that the answers are in accordance with the expectation. 


\begin{tabular}{|c|c|c|c|c|c|c|}
\hline $\mathrm{NO}$ & \multicolumn{3}{|c|}{ RECOGNITION } & \multicolumn{2}{|c|}{ APPLICATION } & REMARKS \\
\hline 1 & $\mathrm{D}$ & $\mathrm{B}$ & $\mathrm{A}$ & $\mathrm{D}$ & $\mathrm{B}$ & English term is easier \\
\hline 2 & $\mathrm{D}$ & B & B & $\mathrm{C}$ & A & $\begin{array}{l}\text { English term is more } \\
\text { common in an article }\end{array}$ \\
\hline 3 & $\mathrm{C}$ & B & B & $\mathrm{C}$ & $\mathrm{B}$ & Using both is fun \\
\hline 4 & B & A & B & A & B & Used frequently \\
\hline 5 & B & A & A & A & A & It is familiar \\
\hline 6 & A & A & $\mathrm{B}$ & $\mathrm{C}$ & $\mathrm{B}$ & Both are familiar \\
\hline 7 & B & $\mathrm{E}$ & B & $\mathrm{C}$ & $\mathrm{C}$ & $\begin{array}{l}\text { I understand Indonesian } \\
\text { better }\end{array}$ \\
\hline 8 & $\mathrm{D}$ & B & B & $\mathrm{C}$ & A & $\begin{array}{l}\text { Many people are more } \\
\text { familiar with the English } \\
\text { term }\end{array}$ \\
\hline 9 & $\mathrm{D}$ & B & A & $\mathrm{D}$ & B & $\begin{array}{l}\text { It is not always easier to } \\
\text { use the Indonesian term }\end{array}$ \\
\hline 10 & $\mathrm{D}$ & A & A & $\mathrm{D}$ & $\mathrm{A}$ & English is more universal \\
\hline 11 & $\mathrm{D}$ & $\mathrm{D}$ & A & $\mathrm{E}$ & A & English is more familiar \\
\hline 12 & $\mathrm{~B}$ & $\mathrm{~B}$ & $\mathrm{~B}$ & $\mathrm{~B}$ & A & English is more familiar \\
\hline 13 & $\mathrm{E}$ & $\mathrm{D}$ & $\mathrm{B}$ & $\mathrm{D}$ & A & English is more familiar \\
\hline 14 & B & $\bar{A}$ & A & $\mathrm{C}$ & $\mathrm{B}$ & Tend to use Indonesian \\
\hline 15 & $\mathrm{E}$ & B & A & $\mathrm{D}$ & A & English is more universal \\
\hline 16 & $\mathrm{C}$ & $\mathrm{A}$ & $\mathrm{A}$ & $\mathrm{D}$ & $\mathrm{A}$ & English is more familiar \\
\hline 17 & $\mathrm{C}$ & B & B & $\mathrm{E}$ & A & English is more familiar \\
\hline 18 & $\mathrm{~A}$ & $\mathrm{~A}$ & $\mathrm{~A}$ & $\mathrm{~A}$ & $\mathrm{~A}$ & English term is easier \\
\hline 19 & $\mathrm{E}$ & B & $\mathrm{A}$ & $\mathrm{D}$ & A & English is more familiar \\
\hline 20 & $\mathrm{D}$ & $\mathrm{B}$ & $\mathrm{B}$ & $\mathrm{D}$ & $\mathrm{A}$ & English is more familiar \\
\hline & $\mathrm{D} / 7$ & $\mathrm{~B} / 10$ & $\begin{array}{l}\mathrm{A}, \mathrm{B} / \\
10\end{array}$ & $\mathrm{D} / 8$ & $\mathrm{~A} / 13$ & \\
\hline
\end{tabular}

1. $\mathrm{A}=2, \mathrm{~B}=5, \mathrm{C}=3, \mathrm{D}=7, \mathrm{E}=3$

2. $\mathrm{A}=7, \mathrm{~B}=10, \mathrm{C}=0 \mathrm{D}=2, \mathrm{E}=1$

3. $\mathrm{A}=21, \mathrm{~B}=6$

4. $\mathrm{A}=3, \mathrm{~B}=1, \mathrm{C}=6, \mathrm{D}=8, \mathrm{E}=2$

5. $\mathrm{A}=13, \mathrm{~B}=6, \mathrm{C}=1$

\section{Recognition}

In term of familiarity of using Indonesian term in IT, about $10 \%$ said extremely familiar, $15 \%$ very familiar, $35 \%$ familiar, $35 \%$ said not very familiar, and $5 \%$ unfamiliar. It can be said that about $40 \%$ of the people are not familiar with Indonesian term. When a list of the Indonesian words in IT were asked, about 35\% said know about 17-20 words , 50\% said know about 13-16 words, 0\% said know about 9-12 words, 10\% said know about 5-8 words and 5\% said know 0-4 words. It can be said that the majority of people (up to $85 \%)$ recognize Indonesian words used in IT. When the people were asked if they know all IT terms as shown in the list, the majority (about 50\%) said know and about 50\% said that they know several of the terms. It can be said the majority of people know all IT terms in the list. 


\section{Application}

In terms of the frequent use of Indonesian terms, about 15\% said always use, 5\% said usually use, $30 \%$ said sometimes use, $40 \%$ said seldom use and $10 \%$ said never use. It can be said that Indonesian terms are unlikely used in IT (about $80 \%$ ). When they know both English and Indonesian terms, about $70 \%$ prefer to use English term, 20\% use Indonesian and about $10 \%$ use both. The reasons why the people are more likely to use English term because they feel English terms are more familiar and easier to understand, English is an international language and it is difficult to translate the terms into Indonesian.

\section{Early Survey on 27 Respondents}

\begin{tabular}{|c|c|c|c|c|c|c|}
\hline NO & \multicolumn{3}{|c|}{ RECOGNITION } & \multicolumn{2}{|c|}{$\begin{array}{l}\text { APPLICATIO } \\
\mathrm{N}\end{array}$} & REMARKS \\
\hline 1 & $\mathrm{~A}$ & $\mathrm{~A}$ & A & A & $\mathrm{B}$ & As required \\
\hline 2 & $\mathrm{~B}$ & $\mathrm{~A}$ & $\mathrm{~A}$ & $\mathrm{~A}$ & $\mathrm{~B}$ & Complementary \\
\hline 3 & $\mathrm{E}$ & $\mathrm{E}$ & A & $\mathrm{E}$ & $\mathrm{A}$ & English is more familiar \\
\hline 4 & $\mathrm{C}$ & $\mathrm{B}$ & A & $\mathrm{C}$ & $\mathrm{A}$ & It is better not to translate \\
\hline 5 & $\mathrm{D}$ & $\mathrm{B}$ & $\mathrm{A}$ & $\mathrm{D}$ & $\mathrm{A}$ & English is more common \\
\hline 6 & $\mathrm{C}$ & $\mathrm{B}$ & A & $\mathrm{C}$ & $\mathrm{B}$ & English is more common \\
\hline 7 & $\mathrm{C}$ & A & A & $\mathrm{D}$ & $\mathrm{C}$ & English is easier \\
\hline 8 & $\mathrm{D}$ & $\mathrm{B}$ & A & $\mathrm{C}$ & $\mathrm{A}$ & English is simpler and easier \\
\hline 9 & B & B & B & $\mathrm{C}$ & B & Depend on condition \\
\hline 10 & $\mathrm{~B}$ & $\mathrm{C}$ & A & $\mathrm{D}$ & $\mathrm{A}$ & English is more familiar \\
\hline 11 & $\mathrm{C}$ & $\mathrm{B}$ & $\mathrm{A}$ & $\mathrm{D}$ & $\mathrm{A}$ & English is more common \\
\hline 12 & $\mathrm{C}$ & $\mathrm{A}$ & A & $\mathrm{B}$ & $\mathrm{A}$ & English is more familiar \\
\hline 13 & $\mathrm{E}$ & $\mathrm{D}$ & A & $\mathrm{E}$ & $\mathrm{A}$ & English is more common \\
\hline 14 & $\mathrm{~A}$ & $\mathrm{~B}$ & $\mathrm{~A}$ & $\mathrm{D}$ & $\mathrm{B}$ & Clearer if use both languages \\
\hline 15 & $\mathrm{D}$ & $\mathrm{C}$ & $\mathrm{A}$ & $\mathrm{D}$ & $\mathrm{A}$ & English is more familiar \\
\hline 16 & $\mathrm{~B}$ & B & A & B & $\mathrm{C}$ & Depend on condition \\
\hline 17 & $\mathrm{D}$ & $\mathrm{B}$ & $\mathrm{B}$ & $\mathrm{D}$ & $\mathrm{A}$ & English is more familiar \\
\hline 18 & $\mathrm{D}$ & $\mathrm{D}$ & A & $\mathrm{E}$ & A & English is more universal \\
\hline 19 & $\mathrm{~A}$ & $\mathrm{~A}$ & $\mathrm{~A}$ & $\mathrm{E}$ & $\mathrm{A}$ & English is international language \\
\hline 20 & $\mathrm{E}$ & $E$ & A & $\mathrm{E}$ & $\mathrm{A}$ & English is more familiar \\
\hline 21 & $\mathrm{C}$ & B & B & $\mathrm{B}$ & $\mathrm{B}$ & Use both to learn English \\
\hline 22 & $\mathrm{C}$ & $\mathrm{B}$ & $\mathrm{B}$ & $\mathrm{B}$ & $\mathrm{B}$ & English is not easy to translate \\
\hline 23 & $\mathrm{~A}$ & $\mathrm{~A}$ & $\mathrm{~A}$ & B & $\mathrm{A}$ & Indonesian term is confusing \\
\hline 24 & $\mathrm{D}$ & $\mathrm{C}$ & $\mathrm{B}$ & $\mathrm{C}$ & $\mathrm{A}$ & English is more universal \\
\hline 25 & $\mathrm{D}$ & B & B & $\mathrm{D}$ & A & English is more familiar \\
\hline 26 & $\mathrm{E}$ & $\mathrm{C}$ & $\mathrm{A}$ & $\mathrm{E}$ & $\mathrm{A}$ & English is more universal \\
\hline 27 & $\mathrm{D}$ & $\mathrm{B}$ & $\mathrm{A}$ & $\mathrm{C}$ & $\mathrm{A}$ & English is more familiar \\
\hline & $\mathrm{D} / 8$ & $\mathrm{~B} / 13$ & $\mathrm{~A} / 21$ & $\mathrm{D} / 8$ & $\mathrm{~A} / 18$ & \\
\hline
\end{tabular}

1. $\mathrm{A}=4, \mathrm{~B}=4, \mathrm{C}=7, \mathrm{D}=8, \mathrm{E}=4$

2. $\mathrm{A}=6, \mathrm{~B}=13, \mathrm{C}=4, \mathrm{D}=2, \mathrm{E}=2$

3. $\mathrm{A}=21, \mathrm{~B}=6$

4. $\mathrm{A}=2, \mathrm{~B}=5, \mathrm{C}=6, \mathrm{D}=8, \mathrm{E}=6$

5. $\mathrm{A}=18, \mathrm{~B}=7, \mathrm{C}=2$ 


\section{Recognition}

In term of familiarity of using Indonesian term in IT, about $16 \%$ said extremely familiar, $16 \%$ very familiar, $28 \%$ familiar, $32 \%$ not very familiar and $16 \%$ unfamiliar. It can be said that nearly $48 \%$ of the people are not familiar with Indonesian term.

When a list of the Indonesian words in IT were asked, about 24\% said know about 17-20 words, $52 \%$ said about $13-16$ words, $16 \%$ said about $9-12$ words, $8 \%$ said about $5-8$ words and 8\% said 0-4 words. When the people were asked if they know all IT terms as shown in the list, the majority (about $80 \%$ ) said know and about $20 \%$ said that they know several of the terms.

\section{Application}

In terms of the frequent use of Indonesian terms, about $8 \%$ said always use, 20\% said usually use, $24 \%$ said sometimes use, $32 \%$ said seldom use and $24 \%$ said never use. When they know both English and Indonesian terms, about 70\% prefer to use English term, $7 \%$ use Indonesian and about $23 \%$ use both. The reasons why the people are more likely to use English term because they feel English terms are more familiar and easier to understand, English is an international language and it is difficult to translate the terms into Indonesian.

\section{Final Survey on 20 Respondents}

\begin{tabular}{|c|c|c|c|c|c|c|}
\hline $\mathrm{NO}$ & \multicolumn{3}{|c|}{ RECOGNITION } & \multicolumn{2}{|c|}{ APPLICATION } & REMARKS \\
\hline 1 & $\mathrm{D}$ & A & $\mathrm{A}$ & $\mathrm{B}$ & A & English term is more common \\
\hline 2 & $\mathrm{D}$ & B & A & $\mathrm{D}$ & A & English is more familiar \\
\hline 3 & $\mathrm{D}$ & A & A & $\mathrm{D}$ & A & English is more common \\
\hline 4 & $\mathrm{C}$ & B & A & A & $\mathrm{C}$ & $\begin{array}{l}\text { Indonesian is becoming } \\
\text { common }\end{array}$ \\
\hline 5 & $\mathrm{D}$ & $\mathrm{D}$ & A & $\mathrm{E}$ & A & English is easier \\
\hline 6 & A & A & A & $\mathrm{D}$ & B & Both are familiar \\
\hline 7 & $\mathrm{E}$ & $\mathrm{D}$ & A & $\mathrm{E}$ & A & English is more common \\
\hline 8 & B & A & $\mathrm{B}$ & $\mathrm{C}$ & A & English is easier to understand \\
\hline 9 & $\mathrm{C}$ & $\mathrm{B}$ & $\mathrm{B}$ & $\mathrm{C}$ & $\mathrm{C}$ & Indonesian is more expressive \\
\hline 10 & $\mathrm{D}$ & $\mathrm{A}$ & A & $\mathrm{D}$ & A & English is more universal \\
\hline 11 & $\mathrm{C}$ & A & A & $\mathrm{C}$ & $\mathrm{C}$ & English is more familiar \\
\hline 12 & $\mathrm{D}$ & A & A & $\mathrm{C}$ & A & English is more familiar \\
\hline 13 & $\mathrm{C}$ & B & A & $\mathrm{D}$ & A & English is more familiar \\
\hline 14 & $\mathrm{C}$ & $\mathrm{B}$ & A & $\mathrm{C}$ & A & Tend to use Indonesian \\
\hline 15 & $\mathrm{C}$ & B & B & $\mathrm{C}$ & $\mathrm{C}$ & English is more universal \\
\hline 16 & $\mathrm{C}$ & $\mathrm{C}$ & $\mathrm{B}$ & $\mathrm{D}$ & A & English did not understand \\
\hline 17 & $\mathrm{D}$ & B & A & $\mathrm{D}$ & A & English is more familiar \\
\hline 18 & $\mathrm{D}$ & B & A & $\mathrm{C}$ & A & English term is easier \\
\hline 19 & $\mathrm{D}$ & $\mathrm{E}$ & B & $\mathrm{C}$ & $\mathrm{A}$ & English is more familiar \\
\hline
\end{tabular}




\begin{tabular}{|l|l|l|l|l|l|l|}
\hline 20 & $\mathrm{~B}$ & $\mathrm{~A}$ & $\mathrm{~A}$ & $\mathrm{~A}$ & $\mathrm{~B}$ & English is more familiar \\
\hline & $\mathrm{D} / 9$ & $\mathrm{~A} \& \mathrm{~B} / 8$ & $\mathrm{~A} / 15$ & $\mathrm{C} / 8$ & $\mathrm{~A} / 14$ & \\
\hline
\end{tabular}

1. $A=1, B=2, C=7, D=9, E=1$

2. $\mathrm{A}=8, \mathrm{~B}=8, \mathrm{C}=1, \mathrm{D}=2, \mathrm{E}=1$

3. $A=15, B=5$

4. $\mathrm{A}=2, \mathrm{~B}=1, \mathrm{C}=8, \mathrm{D}=7, \mathrm{E}=2$

5. $\mathrm{A}=14, \mathrm{~B}=0, \mathrm{C}=6$

\section{Recognition}

In term of familiarity of using Indonesian term in IT, about 5\% extremely familiar, $10 \%$ very familiar, $35 \%$ familiar, $45 \%$ said not very familiar, and $5 \%$ unfamiliar. It can be said that about $50 \%$ of the people are not familiar with Indonesian term.

When a list of the Indonesian words in IT were asked, about 40\% said know 17-20 words, $40 \%$ said know about 13-16 words, 5\% said know about 9-12 words, 10\% said know about 5-8 words and 5\% said know 0-4 words. It can be said that the majority of people (up to $80 \%$ ) recognize Indonesian words used in IT. When the people were asked if they know all IT terms in the list, the majority (about 75\%) said know and about 25\% said that they know several of the terms. It can be said the majority of people know all IT terms in the list.

\section{Application}

In terms of the frequent use of Indonesian terms, about 10\% said always use, 5\% said usually use, $40 \%$ said sometimes use, $35 \%$ said seldom use and $10 \%$ said never use. It can be said that Indonesian terms are unlikely used in IT (about 85\%). When they know both English and Indonesian terms, about $70 \%$ prefer to use English term, 20\% use Indonesian and about $10 \%$ use both. The reasons why the people are more likely to use English term because they feel English terms are more familiar and easier to understand, English is an international language and it is difficult to translate the terms into Indonesian. After grouping the English loan-words into their patterns, the writer then calculated the percentage of the occurrences of each pattern of the borrowed words where there are 3281 English or loan words in total and 145 selected IT words (as can be seen in Table 4.1).

The diagram of the loan word is shown in Figure 4.1, indicating that total borrowing (type-1) is mostly used compared to other types and it is $3.38 \%$ compared to the total words. Partial borrowing (type-2) is $0.98 \%$ and total modification loan word is $0.06 \%$. The remaining types are not available. 


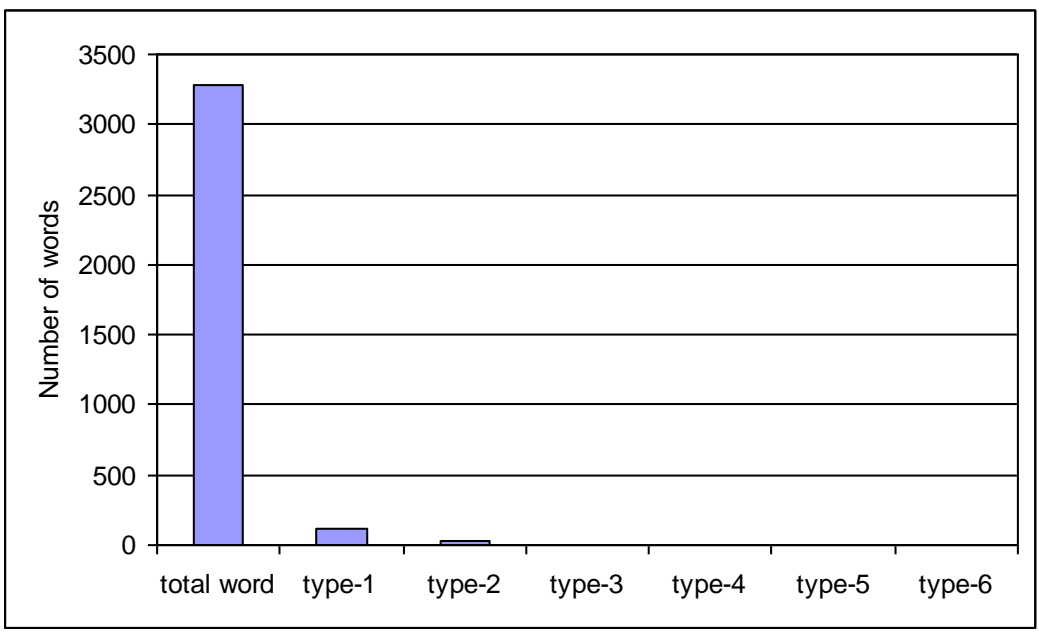

Figure 1. Comparison of total words c.f. IT loan words

In terms of total IT loan words, total borrowing was shown to be mostly used and it took $76.55 \%$ of the total IT words, partial borrowing was $22.07 \%$ and total modified load word was $1.38 \%$. The reason for this was because type- 1 was simply used and according to the questionnaire, the IT people are more familiar with English term rather than the Indonesian term of mixed of both English and Indonesian terms where more than $80 \%$ of the respondents prefer to use English words (in this case, total borrowing) when they involve with IT.

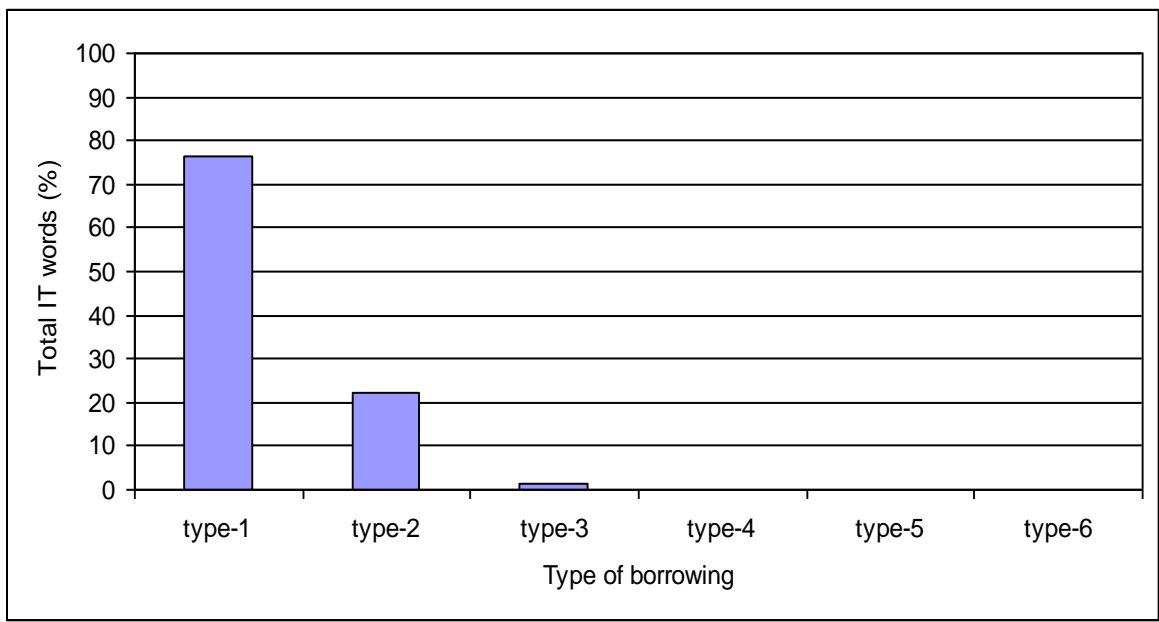

Figure 2. Percentage of IT borrowed words 


\section{Patterns of English Loan Words}

Among six types of pattern of borrowings (Sadtono, 2004), only three types of borrowing are available, namely total borrowing, partial borrowing and total modified load word. Total borrowing has been widely used by IT people and it was 121 words out of 3281 total words (3.38\%) or out of 145 IT words (76.55\%), partial borrowing is 32 words out of 3281 total words $(0.98 \%)$ or out or 145 IT words (22.07\%), and total modification loan word is 2 words out of 3281 total words $(0.06 \%)$ or out of 145 IT words $(1.38 \%)$.

Furthermore, among the total borrowed words, the following words appear more frequently, i.e. the word 'data' $(0.73 \%$ of the total words or $16.55 \%$ of total IT words), the word 'internet' $(0.40 \%$ of the total words or $8.97 \%$ of total IT words $)$ and the word 'network' $(0.24 \%$ of the total words or $5.52 \%$ of total IT words $)$. Among partial borrowing words, the word 'komputer' is mostly used $(0.30 \%$ of the total words or $6.70 \%$ of total IT words). The reason for this is because the four words are extremely closely related to IT world.

\section{Comparison to EYD Rules}

Change in the spelling of English loan words is unavoidable since the spelling should be adapted into Indonesian. This can cause a problem for the writers, who intend to apply the loan words, to spell and pronounce them correctly. In line with this, the Ministry of Education and Culture of the Republic of Indonesia in 1972 has issued a booklet quoted by Anwar (1990) consisting of some explanations for spelling English loan words. Furthermore, Sukono (1984) stated that the government has already released the rules on the use of English loan words and known as EYD rules. The latest version (2005) provides even more examples on this matter. The rules explain how to spell the loan words correctly hence the writers who intend to apply them in their own writing can spell those words correctly. The availability of the EYD rules brings a positive effect to writers who are using English loan words in their own writing.

The research indicates that only 5 out of 7 types of EYD rules are used in the written texts, i.e. rules 1 (phonemic spelling), rules 2 (etymology spelling), rules 5 
(spelling fit), rules 6 (adoption of foreign consonant words) and rules 7 (adjustment of foreign affixes).

Furthermore, among 145 of total IT loan words, 143 words (98.6\%) follow the EYD rules and only 2 words (1.4\%) i.e. the word 'case' becomes 'kasus' violate the EYD rules. It can be said that almost all the IT people follow the EYD rules when they adopt and modify the English words into Indonesian loan words.

\section{Lexicology}

By definition, lexicology is known as part of linguistics, which studies $\underline{\text { words }}$, their nature and meaning, words' elements, relations between words (semantical relations), words groups and the whole lexicon (en.wikipedia.org/wiki/lexicology). In other words, lexicology is a study of making or composing a dictionary.

The current study is important and quite complex in terms of language development. This can be seen from the production of IT glossary by the Centre of Language of the Ministry of National Education. It is supported by a face to face interview with the leader of the production of the IT Glossary (Dr Titon Dutono, M. Eng.). It is found that the background behind the production of this glossary is due to the fact that 'Bahasa Melayu', which is used in Indonesia, Malaysia and Brunei Darussalam, is the third biggest used language after English and Chinese / Mandarin and discussed annually by MABBIM (Majelis Bahasa Brunei Darussalam, Indonesia dan Malaysia) in order to maintain the existence of this language or the lost of Malay language. Another reason for this invention is to accelerate the teaching and learning process of common people such as high school students to learn IT more actively without worrying with difficulties in understanding English terminology.

Even though in reality the IT people recognize and apply more English loan words compared to the Indonesian terms, there is no special lesson to study the Indonesian term which has been designed by the interviewee. The other thing is that the exposure of the people to the IT world in English is much faster than the formal learning process. As the vast development of IT terms internationally, the interviewee expects that the process of adopting the English term can also add the 
creation and coin Indonesian IT terms so that the current glossary can be developed into the proper IT dictionary as meant by the definition of lexicology. Nonetheless, there is no regulation to force the people to use a certain language, either English or Indonesian, say when involve with IT terminology. It depends totally to the people or market needs in which when the people expose to English more than other languages (e.g. Indonesian) then the use of English term become more popular.

\section{Conclusion}

From all the main points that have been discussed in the previous chapters, it can be concluded that out of the six patterns of borrowing only three types are used by IT people. Among those parts, the total borrowing has been popularly used by IT people and it is $3.38 \%$ of the total words or $76.55 \%$ of total IT words. Early survey on 27 respondents and followed by final survey on 20 respondents of IT students at ITS showed that more than $50 \%$ of the people are more familiar with English term, although more than $80 \%$ of them recognize that Indonesian terms are used in IT. According to the questionnaire, the reason for this is because IT people are more familiar with English words and the English words are more easily to understand as the language has been used as an international language.

The second most likely word to use is partial borrowing where it is used by $0.98 \%$ of the total words or $22.07 \%$ of the IT words and the total modification of load words is $0.06 \%$ of the total words or $1.38 \%$ of the IT words. The remaining three types of borrowing are not available. According to the survey, the reason for this is because people discover that it is difficult to translate the terms into Indonesian and about $80 \%$ of the people prefer not to use the Indonesian terms.

Almost all of the English borrowed words (98.6\%) were spelled based on the EYD rules and the remaining (about 1.4\%) violates or not spelled based on the rules of EYD. The current study is expected to contribute more knowledge theoretically to the students of the English Department who are interested in loan words. The students may acquire input regarding theories of loan words, pattern of borrowing, reasons for borrowing, bilingualism, and the description of the change in the parts of speech of the borrowed words. 
Society and IT people in general can put the findings of the current research into a practical use of English loan words correctly. It is expected that the society, particularly the IT people, are able to spell all the English loan words in their writing in accordance with the rules of EYD.

For EFL teachers, the current study is expected to provide theoretical inputs for teaching loan words, such as definitions of loan words, patterns of borrowing, reasons for borrowing, the class-changed of borrowed words and so on. Furthermore, for Indonesian teachers, the findings of the current research can be input theoretically to teach Indonesian vocabularies deriving from English words including how to spell and pronounce the words correctly.

At the end of the day, the study is expected to be a stepping stone for the lexicography researchers to do research in the future using better scopes, instruments, parameters, data sources and data analysis. Some of the English IT loan words investigated in the study were found to violate the rules of EYD. The writer of the thesis suggests the IT people should obey the rules of EYD in spelling the English borrowed words in their Indonesian formal writings such as seminar abstract. Therefore, the readers of IT articles or abstracts can avoid making mistakes in spelling those English loan words when adopted into Indonesian words or terms.

It is suggested to EFL teachers and students, that every subject has its own jargon such as jargon for IT. Hence, the EFL teachers can explain practical inputs in teaching ESP writing, loan words, and the development of loan words in relation to linguistics, particularly the use of loan words, such as definitions of loan words, patterns of borrowing and reasons for borrowing.

Further research on borrowed words is recommended and if collaborated with other similar work, this can help the formation of new dictionary of IT based on the current glossary produced by the Ministry of National Education and involve not only the IT people but also linguist of Indonesian and English to give broader and better perspective in this lexicography development. 


\section{References}

en.wikipedia.org/wiki/information_technology. Downloaded on 15 th March 2008.

Fromkin, V. and Rodman, R. 1984. Introduction to Language. New York: Holt.

Gal, S. 1979. Language Shift. New York. Academic Press.

Glosarium Teknologi Informasi, pusatbahasa.diknas.go.id/glosarium/index.php.

Grosjean, F. 1982. Life with Two Languages. London and Cambridge Mass: Harvard University Press.

Hamid, A. 2006 English Loan Words in the Opini Column of Surya Daily Newspaper. Unpublished S-2 Thesis. Graduate Program Study of Catholic University, Widya Mandala Surabaya.

Hudson, R. A. 1980, Sociolinguistics. Cambridge: Cambridge University Press.

Kamarulzaman, KA and Al Barry, MDY. 2005, Kamus Istilah Serapan. Yogyakarta.

Lee, J. 2008. A statement of Marketing Director of TOEIC/ETS Jakarta in an interview done by the researcher on $25^{\text {th }}$ April 2008.

Method and Research Design:Some examples of different types of research, www.languages.ait.ac.th

Pusat Bahasa Departemen Pendidikan Nasional, 2001, Pedoman Umum Pembentukan Istilah, Balai Pustaka, Jakarta.

Robin, R. H. 1964. General Linguistics. London: Longman.

Sadtono, E. 2004. Is English on The Cross-Road in Indonesia? Unpublished paper presented at the Inaugural CLS International Conference Classic 2002' 1-3 December 2004' on Current Perspective and Future Directions in Foreign Language Studies, National University of Singapore. 